\title{
Ruptured Ectopic Pregnancy in a Patient with Bilateral Tube Ligation
}

\author{
Bilateral Tüp Ligasyonlu Hastada Rüptüre Ekłopik Gebelik
}

\author{
Başak BAYRAM,, Erhan DEDEOĞLU,, ${ }^{2}$ Gülden KARATAĞ ${ }^{3}$ \\ 'Department of Emergency Medicine, Dokuz Eylul University Faculty of Medicine, Izmir; \\ Departments of ${ }^{2}$ Emergency Medicine, ${ }^{3}$ Radiology, Çanakkale State Hospital, Çanakkale, Turkey
}

\begin{abstract}
SUMMARY
Tubal sterilization is a commonly used method of contraception. In the case of sterilization failure, the rate of intrauterine pregnancy is higher than that of ectopic pregnancy. In this article, we present a case of ruptured ectopic pregnancy with a previous history of bilateral tube ligation, presented to our hospital. We aim to underline the necessity of primarily considering ectopic pregnancy as a cause of abdominal pain, even in the presence of tube ligation history in females with childbearing potential.
\end{abstract}

Key words: Ectopic pregnancy; abdominal pain; tubal ligation.

\section{ÖZET}

Tubal sterlizasyon sık uygulanan bir kontrasepsiyon yöntemidir. Sterlizasyon başarısızlığı durumunda ektopik gebelik oranı intrauterin gebelik oranından yüksektir. Bu yazımızda hastanemize başvuran, daha önce bilateral tüp ligasyonu öyküsü olan, rüptüre ektopik gebelik olgusunu sizlerle paylaşmak istedik. Üreme çağındaki kadınlarda tüp ligasyonu öyküsü olsa da ektopik gebeliğin karın ağrısı nedenleri arasında öncelikle düşünülmesinin gerekliliğini vurgulamak amaçladık.

Anahtar sözcükler: Ektopik gebelik; karın ağrısl; tüp ligasyonu.

\section{Introduction}

Ectopic pregnancy is a significant cause of morbidity and mortality in females with childbearing potential. Ruptured ectopic pregnancy and hemorrhage are the leading causes of maternal mortality in the first trimester. ${ }^{[1]}$ Therefore, early diagnosis and treatment is important in preventing potential complications. Tubal sterilization is a common method of contraception. However, the rate of ectopic pregnancy is high in failed cases. ${ }^{[2]}$ The rate of ectopic pregnancy is 15 $20 \%$ in the case of sterilization failure. In fact, a study in a series of ectopic pregnancy cases revealed $4.53 \%$ of these cases had tube ligation. ${ }^{[3]}$ In this case report, we present a patient with ruptured ectopic pregnancy who had bilateral tube ligation.

\section{Case Report}

A 43-year-old female patient was brought to our emergency department with complaints of abdominal pain, diarrhea and fatigue. The patient explained that she had called an ambulance upon feeling faint. Patient evaluation in the emergency department revealed a blood pressure 90/60 $\mathrm{mmHg}$, heart rate 112 beats per minute, a body temperature of $36^{\circ} \mathrm{C}$ and breathing count $16 / \mathrm{min}$ and the physical examination revealed no significant findings in the abdomen other than diffuse abdominal sensitivity. The initial hemoglobin count was $9.5 \mathrm{~g} / \mathrm{dL}$ and total white cell count was $14.1 \times 10^{9} / \mathrm{L}$. Upon enquiry, the patient reported having regular menstrual periods; since she had also had ligation many years ago, no ß-hCG measurement was scheduled. The

Submitted (Geliş tarihi): 08.05.2011 Accepted (Kabul tarihi): 06.01.2012 Published online (Online baskı): 06.01.2012 Correspondence (Illetişim): Başak Bayram, M.D. Dokuz Eylül Üniversitesi Tıp Fakültesi Acil Tıp Anabilim Dalı, İzmir, Turkey e-mail (e-posta): basakdr@yahoo.com 

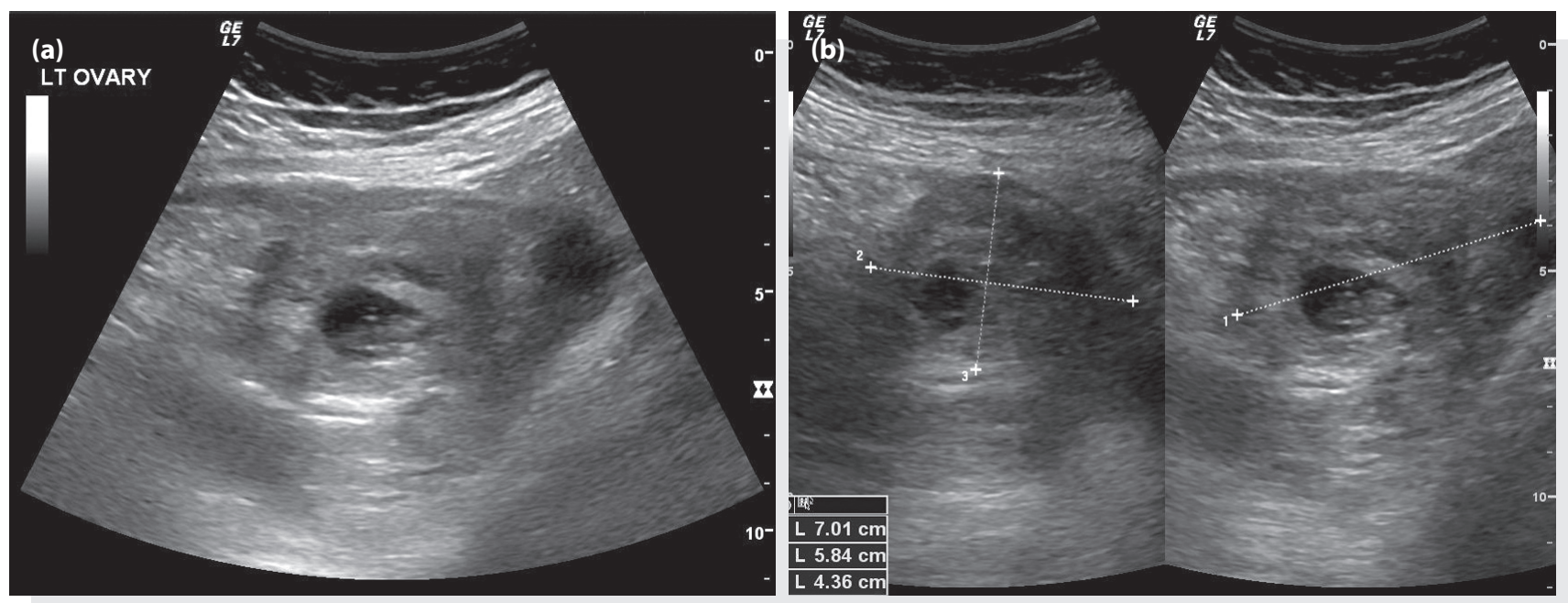

Figure 1. (a, b) Transabdominal ultrasound image showing the fetus located in the left ovary.

patient was placed in observation unit since she had no severe pain and no significant physical examination findings.

The patient, having exhibited a deterioration of her overall status during observation period, was detected to have a diffuse abdominal rebound on repeated examination. The abdominal ultrasonography revealed free abdominal fluid and a fetus was detected in the left ovary (Figures 1 , 2). Upon this detection, $\beta$-hCG level was investigated. Urine pregnancy test was positive. The second hemoglobin count was $5.9 \mathrm{~g} / \mathrm{dL}$, total white cell count was $15.7 \times 10^{9} / \mathrm{L}$ and the level of serum $\beta$-hCG was $8945 \mathrm{mlU} / \mathrm{mL}$. Gynecology specialist consultation was requested immediately. The patient was operated under the diagnosis of ruptured ectopic pregnancy. Bilateral salphingectomy and peritoneal lavage was performed during the surgery and patient was discharged without complications on the fifth day.

\section{Discussion}

Usually, patients undergoing tubal sterilization are considered to have a lower risk of pregnancy. However, tubal sterilization application can fail, and in cases of failure, the resulting pregnancy could very well be ectopic. Considering all the methods of tubal sterilization, the 10-year cumulative ectopic pregnancy risk is 7.3 per 1000 procedures. Of all the methods, bilateral tubal coagulation is the one known to cause the highest risk of ectopic pregnancy. ${ }^{[4]}$ Furthermore, the risk for patients following tubal sterilization is not reduced but maintained at the same rate. Ectopic pregnancy is a significant cause of mortality and morbidity in females with childbearing potential. However, the potential of failure to establish a diagnosis at presentation is high. $12 \%$ of patients are diagnosed not at the initial presentation but at the next presentation. ${ }^{[5]}$
The emergency department physicians should be alert to the potential of ectopic pregnancy in all females of childbearing potential presenting to the emergency department. Ultrasonography and B-hCG are recommended for establishing the diagnosis. ${ }^{[6,7]}$ The presence of a tubal sterilization history should not draw the physician away from establishing the diagnosis; in fact, the potential for ectopic pregnancy should be kept in mind in such a patient with a positive B-hCG result. $95 \%$ of the ectopic pregnancies occur in the fallopian tubes; $3.2 \%$ may occur in the ovaries and $1.3 \%$ may occur in the abdomen. ${ }^{[8]}$ Our case was also detected to have an ovarian ectopic pregnancy. The ultrasonographic evaluation reveals the ovarian pregnancies as cysts with a large echogenic outer circle in or on the ovary. The yolk sac or embryo detected in ultrasonography in our patient is a relatively rare

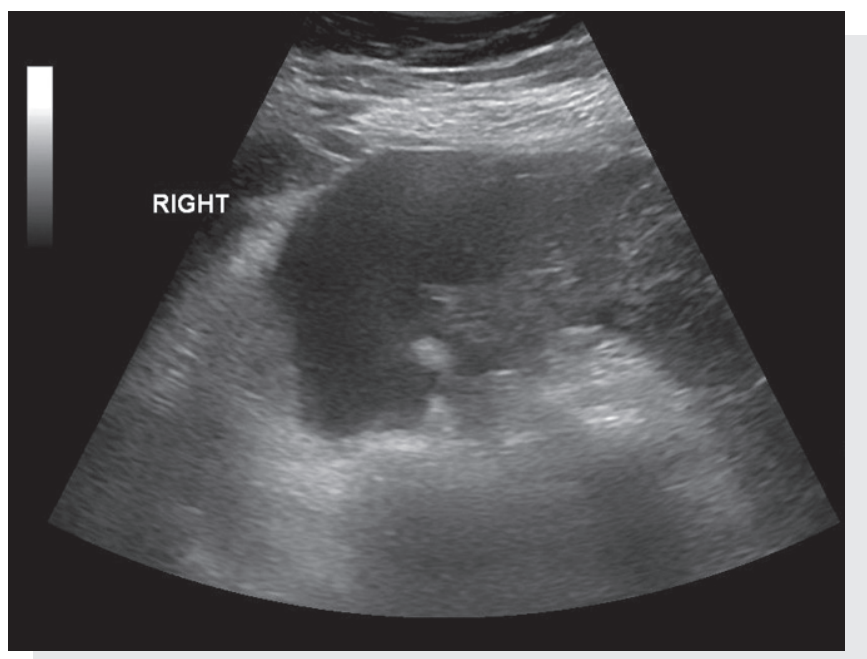

Figure 2. Transabdominal ultrasound image showing intraabdominal free fluid. 
condition. ${ }^{[9]}$ However, one should note that transabdominal ultrasonography could be insufficient, particularly in early pregnancy. In cases with a ß-hCG level below 1,000 mlU/mL, performing a transvaginal ultrasonography and scheduling follow-up in high-risk patients is important, even if no such risk has been demonstrated by the imaging techniques.

\section{Conclusion}

Ectopic pregnancy is an entity that is difficult to diagnose, and which may be fatal if left undiagnosed. Being of childbearing potential should alone be considered as a risk factor and definitely be included in the differential diagnoses of the emergency physician. The history of tubal sterilization is not sufficient to rule out this condition; in fact, this condition should be primarily considered in case of pregnancy.

\section{References}

1. Farquhar CM. Ectopic pregnancy. Lancet 2005;366:583-91.

2. Brenner PF, Benedetti T, Mishell DR Jr. Ectopic pregnancy following tubal sterilization surgery. Obstet Gynecol 1977;49:323-4.

3. Shah JP, Parulekar SV, Hinduja IN. Ectopic pregnancy after tubal sterilization. J Postgrad Med 1991;37:17-20.

4. Peterson HB, Xia Z, Hughes JM, Wilcox LS, Tylor LR, Trussell J. The risk of ectopic pregnancy after tubal sterilization. U.S. Collaborative Review of Sterilization Working Group. N Engl J Med 1997;336:762-7.

5. Robson SJ, O'Shea RT. Undiagnosed ectopic pregnancy: a retrospective analysis of 31 'missed' ectopic pregnancies at a teaching hospital. Aust N Z J Obstet Gynaecol 1996;36:182-5.

6. ACOG practice bulletin. Medical management of tubal pregnancy. Number 3, December 1998. Clinical management guidelines for obstetrician-gynecologists. American College of Obstetricians and Gynecologists. Int J Gynaecol Obstet 1999;65:97-103.

7. ACEP Clinical Policies Committee and Clinical Policies Subcommittee on Early Pregnancy. American College of Emergency Physicians. Clinical policy: critical issues in the initial evaluation and management of patients presenting to the emergency department in early pregnancy. Ann Emerg Med 2003;41:123-33.

8. Bouyer J, Coste J, Fernandez H, Pouly JL, Job-Spira N. Sites of ectopic pregnancy: a 10 year population-based study of 1800 cases. Hum Reprod 2002;17:3224-30.

9. Comstock C, Huston K, Lee W. The ultrasonographic appearance of ovarian ectopic pregnancies. Obstet Gynecol 2005;105:42-5. 